\title{
Phytostimulation and growth promotion activities of Trichoderma spp. on groundnut (Arachis hypogaea L.) crop
}

M. Ayyandurai*

Department of Plant Pathology, Agriculture College and Research Institute, Tamil Nadu Agricultural University, Madurai - 625104 (Tamil Nadu), India

\section{R. Akila}

Department of Plant Pathology, Agriculture College and Research Institute, Tamil Nadu Agricultural University, Madurai - 625104 (Tamil Nadu), India

\section{K. Manonmani}

Department of Plant Pathology, Agriculture College and Research Institute, Tamil Nadu Agricultural University, Madurai - 625104 (Tamil Nadu), India

M. Theradimani

Department of Plant Pathology, Agriculture College and Research Institute, Tamil Nadu Agricultural University, Madurai - 625104 (Tamil Nadu), India

\section{S. Vellaikumar}

Department of Biotechnology, Agriculture College and Research Institute, Tamil Nadu Agricultural University, Madurai - 625104 (Tamil Nadu), India

*Corresponding author. Email: ayyanduraipatho9793@gmail.com

\section{Article Info}

https://doi.org/10.31018/

jans.v13i4.2936

Received: August 21, 2021

Revised: October 17, 2021

Accepted: October 22, 2021

\section{How to Cite}

Ayyandurai, M. et al. (2021). Phytostimulation and growth promotion activities of Trichoderma spp. on groundnut (Arachis hypogaea L.) crop. Journal of Applied and Natural Science, 13(4), 1172 - 1179. https://doi.org/10.31018/jans.v13i4.2936

\begin{abstract}
Groundnut (Arachis hypogaea L.) suffers from many soil borne pathogens that deteriorate the quality of the seeds and are responsible for high yield loss. Practically Trichoderma sp. is used for seed treatment, it minimizes the seed and soil borne pathogens and supports plant growth promotion activities. In the present study, five different isolates of Trichoderma spp. were isolated from groundnut ( $A$. hypogaea ) rhizosphere soil. All the five isolates were confirmed by morphological methods and using molecular tools through Polymerase Chain Reaction (PCR) amplification of Internal Transcribed Spacer (ITS) region of Trichoderma sp. and DNA gets amplified in $650 \mathrm{bp}$ to $700 \mathrm{bp}$. Trichoderma spp. were molecularly identified as T(SP)-20 (Trichoderma longibrachiatum), T(AR)-10 ( $T$. asperellum), T(VT)-3 ( $T$. hamatum), T(BI)-16 ( $T$. longibrachiatum), $\mathrm{T}(\mathrm{TK})-23$ ( $T$. citrinoviride). Phytostimulation activities of all the six isolates viz., phosphate solubilization, Ammonia production, IAA production, and Siderophore production, were evaluated. Among the six isolates, T(SP)-20, T(AR)-10, and TNAU-TA showed higher phytostimulation activities. The growth promotion of Trichoderma spp. on groundnut was assessed through the roll towel method. The isolate $T$ (SP)-20 ( $T$. longibrachiatum) produced the highest germination percentage of 93.33 and vigor index of 2246.2. This work developed a new isolate of $T$. longibrachiatum (T(SP)-20) which is a native isolate having significant phytostimulation and growth promotion activities and it could be exploited for other soil borne disease managing successfully.
\end{abstract}

Keywords: Groundnut, growth promotion, Sclerotium rolfsii, Soil-borne pathogens, Trichoderma spp.

\section{INTRODUCTION}

Groundnut is an important oilseed crop that belongs to the family of Leguminosae. It is grown widely throughout the world under various agroclimatic conditions. It is a valuable source of all essential nutrients. In India, Gujarat ranks first in groundnut area (16 lakh ha) with the production of 46 lakh tonnes. The highest productivity of $2980 \mathrm{~kg} / \mathrm{ha}$ was recorded in the State of Tamil
Nadu, while the productivity was only about $2751 \mathrm{~kg} / \mathrm{ha}$ in Gujarat (www.indiastat.com). Groundnut is infected with a wide range of seed and soil borne pathogens like Aspergillus niger, Sclerotium rolfsii, Macrophomina phaseolina. The infection by these pathogens caused the qualitative and quantitative losses of the crop. The extensive use of chemical fungicides and fertilizer resulted in the emergence of fungicide-resistant pathogens and concerns have been raised over the residual 
effects on the environment and human health, so biocontrol agents (BCAs) are an alternative to fungicides (Ons et al., 2020). It is important to highlight that pre-treating seeds with biocontrol agents is an alternative for controlling severe diseases that reduces yields more than $30 \%$, making peanut production economically non-viable (Paredes et al., 2017). Trichoderma spp. widely distributed soilborne antagonistic fungi used for seed treatment and significantly suppresses the growth of plant pathogenic microorganisms and enhance the rate of plant growth of groundnut Siddiquee et al., 2017). The seed and soil borne pathogen infection is reduced by seeds are treated with Trichoderma spp., which adhere the seed coat region to successfully colonize the harmful pathogens and also induce the growth of the plants (Prasad et al 2020). Halifu et al., (2019) reported that secretion of cell wall degrading enzymes such as cellulase, xylanase and glucanases by Trichoderma species impairs the microbial cell functions such as nutrient absorption in the rhizosphere and also strengthen the immune system of host plant. Trichoderma spp. enhanced plant growth by releasing hormonelike compounds that boost up root development and plant growth. The rapid growth of plant induces microbial populations through the secretion of significant amounts of root exudates, which in turn increases the availability of nutrients for microbial consumption (Carvalhais et al., 2015). Hence, Trichoderma spp. represents the most widely employed biocontrol agents, playing a useful role as plant growth promoters and valuable sources of secondary metabolites. The present study focuses on the selection of efficient Trichoderma sp. based on the biochemical activities and growth promotion on groundnut ( $A$. hypogaea L.)

\section{MATERIALS AND METHODS}

\section{Isolation of Trichoderma spp. from the soil}

The sandy, loamy soil samples were collected from five different groundnut-grown regions such as Alanganallur, Servarayanpatti, Vovval thotam, Bodi, and Thirupparankundram, of Tamil Nadu, in India. Trichoderma spp. were isolated through soil dilution plating technique in Trichoderma selective medium (TSM) (Elad and Chet, 1983). The isolates were further purified through a single hyphal tip method and sub cultured on PDA medium and incubated at $28 \pm 2^{\circ} \mathrm{C}$ for five days (Kumar et al., 2014).

\section{Morphological characters and molecular confirmation of Trichoderma spp.}

The isolated five different Trichoderma spp. viz., T(SP)20 (Trichoderma longibrachiatum Acc. No - MZ277378), T(AR)-10 (T. asperellum Acc. No MZ277326), T(VT)-3 ( $T$. hamatum Acc. No MZ675442), T(BI)-16 ( $T$. longibrachiatum Acc. No MZ802988), T(TK)-23 (T. citrino- viride) were confirmed by morphological characters such as mycelia, conidia, phialides, colony growth pattern, and color (Rifai, 1969). The genomic DNA of Trichoderma spp. was isolated by Cetyl trimethylammonium bromide(CTAB) method (Narayanasamy and Saravana, 2009). The reaction mixture for Polymerase Chain Reaction (PCR) amplification of the DNA contained the volume of $10 \mu \mathrm{l}$ in which the master mix was of $5 \mu \mathrm{l}, 1 \mu \mathrm{l}$ of forward and reverse primer individually, 2 $\mu \mathrm{l}$ of DNA, and $1 \mu \mathrm{l}$ of sterile distilled water. Mastermix had $0.25 \mathrm{mM} \mathrm{dNTP}, 1.5 \mathrm{mM} \mathrm{MgCl}_{2}$, Taq polymerase and buffer. The sequence of genomic DNA was identified using the Forward primer: ITS 1(5'- TCCGTAGGTGAACCTGCGG-3') and Reverse primer: ITS 4 (5'- TCCTCCGC TTATTGA TATGC-3'). PCR was done with a master cycler with an inbuilt program for initial denaturation at $94{ }^{\circ} \mathrm{C}$ for 5 minutes, continued by 35 cycles composed of denaturing at $94{ }^{\circ} \mathrm{C}$ for 1 minute, annealing at $46^{\circ} \mathrm{C}$ for 1 minute, extension at $72{ }^{\circ} \mathrm{C}$ for 1 minute ending with a final extension at $72{ }^{\circ} \mathrm{C}$ for 10 minutes (White et al., 1990). The PCR products were subjected to analysis by gel electrophoresis on 1.5 per cent agarose gel, visualized and documented under UV light.

\section{Phytostimulation activities}

In the present study, all six Trichoderma spp. viz., [T (SP)-20, T(AR)-10, T(VT)-3, T(BI)-16, T(TK)-23, TNAU$\mathrm{TA}$ ] were assessed for the biochemical characteristics such as siderophore production, IAA production, phosphate solubilization, and ammonia production.

\section{a. Siderophore production}

Chrom Azurol $S$ blue agar medium (CAS) medium was used to detect siderophore production of Trichoderma sp. ((Khamna et al., 2009). The 8mm plug of Trichoderma sp was placed on the CAS medium containing Petri plate, which was incubated at $28^{\circ} \mathrm{C}$ for five days. After the incubation, color changes from yellow to orange zone produced around the colony indicated the production of siderophore by Trichoderma spp. (Schwyn and Neilands, 1987).

\section{b. IAA production}

Salkowski reagent was used for the detection and quantification of IAA (Hartmann et al., 1983). A $20 \mathrm{ml}$ of PDA broth containing conical flask was inoculated with all the six isolates of Trichoderma spp. Individually, and each flask was amended with $0.1 \%$ tryptophan served as treatment, a precursor for IAA. The broth without adding $0.1 \%$ tryptophan was maintained as a control (Gordon and Paleg, 1957). The broths were incubated at $28 \pm 2{ }^{\circ} \mathrm{C}$ for 5 days. After that broth was centrifuged at $10000 \mathrm{rpm}$ for 10 minutes. One $\mathrm{ml}$ of supernatant was added in $2 \mathrm{ml}$ Salkowski's reagent (1 $\mathrm{ml} 0.5 \mathrm{M} \mathrm{FeCl}_{2}$ in $50 \mathrm{ml} 35 \%$ perchloric acid) and kept 
in dark for 30 minutes. The development of pink color indicates the production of IAA.

\section{c. Phosphate solubilization}

The Pikovskayc's broth was prepared in a sterile conical flask and added with $5 \mathrm{~g} / \mathrm{l}$ of tricalcium phosphate. The broth was inoculated with 7 days old culture Trichoderma sp and incubated at $28 \pm 2{ }^{\circ} \mathrm{C}$ for four days. Trichoderma filtrate $(50 \mu \mathrm{l})$ was added with $(5 \mu \mathrm{l})$ of ammonium molybdate and shaken after adding chlorostannous acid $13 \mu \mathrm{l}$, and distilled water $(2.5 \mathrm{ml})$ was added. Then $\mathrm{K}_{2} \mathrm{HPO}_{4}$ was added to make different concentrations of $(0.2 \mathrm{ppm}, 0.4 \mathrm{ppm}, 0.6 \mathrm{ppm}, 0.8 \mathrm{ppm}$, and $1 \mathrm{ppm}$ standard solution. The development of blue color indicated phosphate solubilization. The blue color intensity was read with $600 \mathrm{~nm}$ in a spectrophotometer (King, 1932).

\section{d. Ammonia production}

Trichoderma spp. culture was inoculated into the peptone water amended boiling tube. After 72hours, the addition of Nessler's reagent resulted in turning the brown color from yellow indicated a positive result of ammonia production (Dye, 1962).

\section{Roll towel method}

Efficacy of effective Trichoderma spp. on seed germination and growth promotion activity was assessed through the standard roll towel method ( International Seed Testing Association, 1993). All the six isolates of Trichoderma spp. were grown in PDA broth at $28 \pm 2^{\circ} \mathrm{C}$ for five days. After that, centrifuged at $10000 \mathrm{rpm}$ for 5 min; finally, the supernatant was discarded, and the pellet should be dissolved in sterile water. Trichoderma sp. suspension at $10^{8} \mathrm{cfu} / \mathrm{ml}$ containing $100 \mathrm{mg}$ of Carboxy Methyl Cellulose (CMC) was prepared. Likewise, the suspension of all the six isolates of Trichoderma spp. were prepared. The groundnut seeds were treated with $0.1 \%$ mercuric chloride for $5 \mathrm{~min}$ and rinsed with sterile distilled water for surface sterilisation. The surface sterilized seed was soaked in Trichoderma sp. suspension for $12 \mathrm{hrs}$. In the case of control, the seed was soaked in sterile water. The soaked seeds of both treatment and control were arranged in wet blotter paper, rolled carefully, and then incubated for ten days; after the incubation, the germination percentage, root length, shoot length and vigor index were calculated (Agrawal and Agrawal, 2013).

Vigor Index $=$ Germination $\% \times$ mean total length of the seedling (root length + shoot length) $\quad$.......Eq.1

\section{Statistical analysis}

Mean differences of the treatment were evaluated with ANOVA at a significant level $(P<0.05)$, and means were compared by Duncan's Multiple Range Test (Gomez and Gomez, 1984).

\section{RESULTS AND DISCUSSION}

Trichoderma spp. were isolated from five different groundnut grown regions in Tamil Nadu such as Alanganallur, Servarayanpatti, Vovval thotam, Thiruparankundram, and Bodi and designated with the isolated code like T(SP)-20 ( $T$. longibrachiatum), T(SP) -10 ( $T$. asperellum), T(VT)-3 ( $T$. hamatum), T(TK)-23 ( $T$. citrinoviride), $\mathrm{T}(\mathrm{BI})-16$ ( $T$. longibrachiatum) are shown in Table 1

\section{Morphology of Trichoderma spp.}

Cultural characteristics comprising growth rate, color, and colony appearance were regarded as taxonomically useful characteristics for Trichoderma spp. (Samuels et al., 2002). The cultural growth of fungal antagonist Trichoderma spp. differed from dull to dark green color in ring-like zones. The antagonists identified morphologically with their colony characters showed that $\mathrm{T}(\mathrm{SP})-20$ was greenish in color with a yellowish inner ring, and $T(A R)-10$ was dark green with sparse ring-like growth of culture (Table 2; Fig.1; Fig.2). Similarly, Sharma and Singh (2014) reported that Trichoderma sp initially produced flat pustules in concentric rings. The pustules appeared powdery due to dense conidiation. T. virens isolate showed predominant effuse conidiation without formation of any pustule.

\section{Molecular characteristics of Trichoderma spp.}

All the six Trichoderma spp. were characterized molecularly by PCR using a universal primer of ITS1 and ITS4 and produced the amplicon size in the range of 650 bp to 700 bp (Fig.3). The PCR amplified Trichoderma spp. product was sent to the Eurofins Genomics Bangalore, India for DNA sequencing, and the sequenced product was submitted to the NCBI database. The accession numbers received $\mathrm{T}(\mathrm{SP})-20$ (Trichoderma longibrachiatum Acc. No MZ277378), T (SP)-10 ( $T$. asperellum MZ277326), T(VT)-3 ( $T$. hamatum Acc. NoMZ675442), T(TK)-23 ( $T$. citrinoviride) are (Table 2). Similarly, Castle et al. (1998) reported that PCR of T. koningii and T. longibrachiatum. $T$. citrinoviride, $T$. koningii, $T$. atroviride isolates using universal primers (ITS1, and ITS4 ) were amplified in 700 bp. Also, Shahid (2013) reported universal primers (ITS-1\& ITS-4) used for the amplification of $28 \mathrm{~S}$ rRNA gene fragment of $T$. longibrachiatum that produced a sharp band of about 654-700 bp on the gel.

\section{Phytostimulation activities of Trichoderma spp.}

The isolates, namely $\mathrm{T}(\mathrm{SP})-20 . \mathrm{T}(\mathrm{AR})-10, \mathrm{~T}(\mathrm{VT})-3, \mathrm{~T}$ (TK)-23, TNAU-TA, showed a positive result in phosphate solubilization by observing the blue color appearance. T(SP)-20, T(AR)-10 produced the high blue color intensity among the six isolates. The isolate $\mathrm{T}(\mathrm{BI})-16$ 
Table 1. Trichoderma spp. isolated from rhizosphere region of groundnut plant

\begin{tabular}{lllllll}
\hline \multirow{2}{*}{ S.No } & \multirow{2}{*}{ Place of collection } & Districts & Trichoderma sp. & Isolate & \multicolumn{2}{c}{ Geo-coordinates } \\
\cline { 6 - 7 } & & & code & Latitude & Longitude \\
\hline 1 & Servarayanpatti & Sivagangai & T. longibrachiatum & T(SP)-20 & $9.86670^{\circ} \mathrm{N}$ & $78.4832^{\circ} \mathrm{E}$ \\
2 & Alanganallur & Madurai & T. asperellum & T(AR)-10 & $10.0474^{\circ} \mathrm{N}$ & $78.0904^{\circ} \mathrm{E}$ \\
3 & Vavval Thottam & Madurai & T. hamatum & T(VT)-3 & $9.9699^{\circ} \mathrm{N}$ & $78.2040^{\circ} \mathrm{E}$ \\
4 & Bodi & Theni & T. longibrachiatum & T(BI)-16 & $10.0106^{\circ} \mathrm{N}$ & $77.3497^{\circ} \mathrm{E}$ \\
5 & $\begin{array}{l}\text { Thirupparan } \\
\text { kundram }\end{array}$ & Madurai & T. citrinoviride & T(TK)-23 & $9.8823^{\circ} \mathrm{N}$ & $78.0720^{\circ} \mathrm{E}$ \\
6 & Culture collection of & Coimbatore & T. asperellum & TNAU-TA & $11.0122^{\circ} \mathrm{N}$ & $76.9354^{\circ} \mathrm{E}$ \\
\hline
\end{tabular}

Table 2. Morphological characterization and molecular confirmation of Trichoderma spp.

\begin{tabular}{lll}
\hline Isolate code & Colony character & Accession number \\
\hline $\mathrm{T}(\mathrm{SP})-20$ & Greenish towards outside with yellowish inner ring & $\begin{array}{l}\text { Trichoderma longibrachiatum } \\
\text { (MZ277378) }\end{array}$ \\
$\mathrm{T}(\mathrm{AR})-10$ & Dark green with sparse ring-like growth & Trichoderma asperellum (MZ277326) \\
$\mathrm{T}(\mathrm{VT})-3$ & Dull green culture with ring-like pattern & Trichoderma hamatum (MZ675442) \\
$\mathrm{T}(\mathrm{BI})-16$ & Light green to yellowish culture with whitish mycelial growth & $\begin{array}{l}\text { Trichoderma longibrachiatum } \\
\text { (MZ802988) }\end{array}$ \\
$\mathrm{T}(\mathrm{TK})-23$ & Complete dull green tufts or pustules & Trichoderma citrinoviride \\
\hline
\end{tabular}

Table 3. Phytostimulation activities of Trichoderma sp.

\begin{tabular}{llllll}
\hline S.No. & ISOLATE & $\begin{array}{l}\text { Phosphate } \\
\text { Solubilization }\end{array}$ & $\begin{array}{l}\text { Ammonia pro- } \\
\text { duction }\end{array}$ & IAA Production & $\begin{array}{l}\text { Siderophore } \\
\text { production }\end{array}$ \\
\hline 1 & T(SP)-20 & ++ & + & +++ & + \\
2 & T(AR)-10 & + & + & ++ & + \\
3 & T(VT)-3 & + & - & + & ++ \\
4 & T(BI)-16 & + & - & + & + \\
5 & T(TK)-23 & - & + & + & ++ \\
6 & TNAU-TA & ++ & ++ & +++ & - \\
7 & CONTROL & - & - & - & + \\
\hline
\end{tabular}

“+++”, good producers; “++”, medium producers; “+”, low producers; “-“, negative reaction

did not show any phosphate solubilization reaction (Table 3; Fig.4). Our results were in accordance with the findings of Azarmi et al. (2011), who reported that T. harzianum boosted the phosphorus and other nutrient content in tomato seedlings, as well as stem height and diameter, and fresh and dry weights.

All the Trichoderma spp. showed deep yellowish to brown color during the test of ammonia production except control. The dark brown color was observed in $T$. longibrachiatum (T(SP)-20), T. asperellum (T(AR)-10), T. asperellum (TNAU-TA) which indicated that production of ammonia. (Table 3, Fig.4). Similarly, Prasad et al. (2017) reported that ten Trichoderma spp. used for the biochemical test of ammonia production, exhibited positive reaction by the appearance of brown color (positive result) except $T$. harzianum-6.

Indole acetic acid (IAA) production of Trichoderma spp. was observed to be positive for all the six Trichoderma spp. production of reddish-pink color except for the control plate. Isolates of T(SP)-20, T(AR)-10, TNAU-TA were noticed with the highest IAA production. The IAA was highly noticed in the isolate $T(S P)-20$, which induced higher growth than the remaining isolates. The IAA was responsible for the growth promotion activity (Table 3; Fig.4). Guey et al. (2018) reported that out of 20 Trichoderma strains, only eight strains showed the maximum IAA production. Among the eight strains, TG 4 showed maximum $(90 \mu \mathrm{g} / \mathrm{ml})$ IAA production. In Arabidopsis, seedlings treated with $T$. virens, or $T$. atroviride produced auxin-related substances such as indole-3-acetic acid, indole-3-acetaldehyde, and indole-3ethanol, which were responsible for increased biomass production (Contreras-Cornejo et al., 2014).

All the Trichoderma spp. isolates showed siderophore production in the plate assay in which they showed a prominent yellow color zone. Among the six Trichoder- 


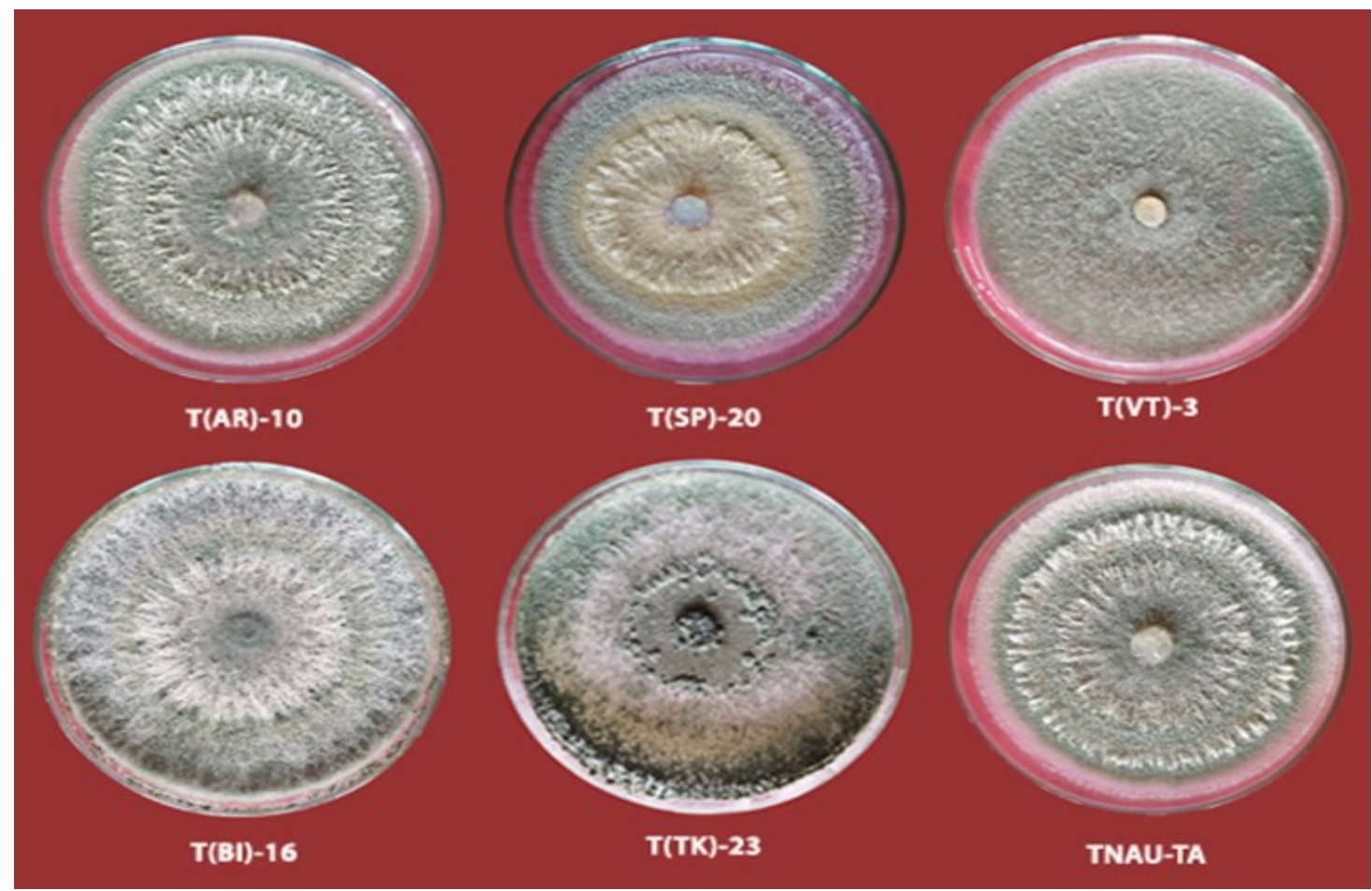

Fig.1. Isolates of Trichoderma spp.

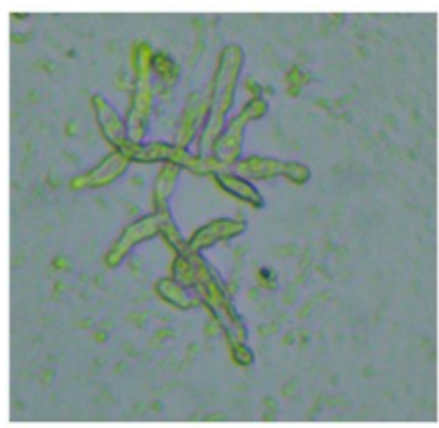

T(SP)-20

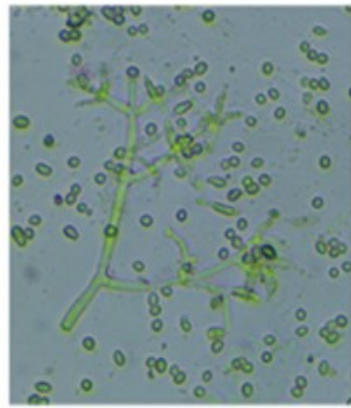

T(AR)-10

Fig. 2. Showing conidia with phialides of Trichoderma spp.

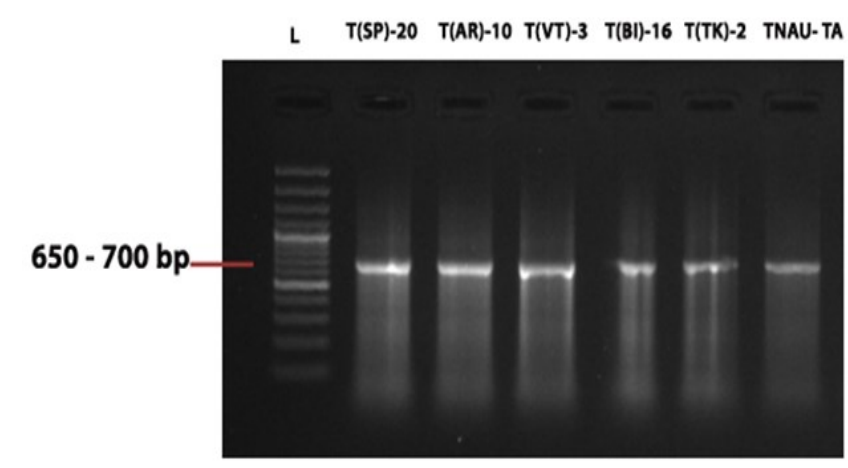

L- 100 bp ladder

Fig. 3. Showing PCR amplification of Trichoderma spp.

Table 4. Growth promotion activities of Trichoderma spp.

\begin{tabular}{llllll}
\hline S.No. & ISOLATE & Shoot length $(\mathbf{c m})$ & Root length(cm) & Germination \% & Vigor index \\
\hline 1 & T(SP)-20 & $10.6^{\mathrm{a}}(19.00)$ & $13.4^{\mathrm{a}}(21.47)$ & $93.33^{\mathrm{a}}(75.03)$ & $2246.2^{\mathrm{a}}$ \\
2 & $\mathrm{~T}(\mathrm{AR})-10$ & $8.7^{\mathrm{b}}(17.15)$ & $11.6^{\mathrm{b}}(19.91)$ & $86.66^{\mathrm{b}}(68.58)$ & $1762.2^{\mathrm{b}}$ \\
3 & $\mathrm{~T}(\mathrm{VT})-3$ & $8.3^{\mathrm{c}}(16.74)$ & $8.4^{\mathrm{c}}(16.84)$ & $80^{\mathrm{c}}(63.43)$ & $1341.3^{\mathrm{c}}$ \\
4 & $\mathrm{~T}(\mathrm{BI})-16$ & $6.5^{\mathrm{e}}(14.77)$ & $8.5^{\mathrm{c}}(16.95)$ & $73.33^{\mathrm{d}}(58.90)$ & $1107.3^{\mathrm{de}}$ \\
5 & $\mathrm{~T}(\mathrm{TK})-23$ & $8.5^{\mathrm{bc}}(16.95)$ & $7.6^{\mathrm{d}}(16.00)$ & $66.66^{\mathrm{e}}(54.73)$ & $1075.5^{\mathrm{e}}$ \\
6 & TNAU-TA & $7.4^{\mathrm{d}}(15.78)$ & $6.9^{\mathrm{e}}(15.22)$ & $80^{\mathrm{c}}(63.43)$ & $1150.13^{\mathrm{d}}$ \\
& CONTROL & $2.8^{\mathrm{f}}(9.63)$ & $4.5^{\mathrm{f}}(12.24)$ & $46.66^{\mathrm{f}}(43.08)$ & $342.2^{\mathrm{f}}$
\end{tabular}

Values are the means of three replicates; means in a column followed by the same letters are not significantly different according to Dungun's multiple range test at $P=0.05$. Values in parentheses are arcsine transformed values 


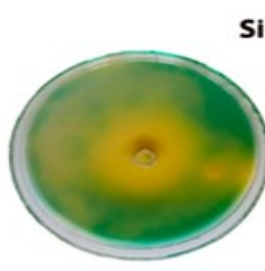

$T(S P)$ - 20
Siderophore productiom

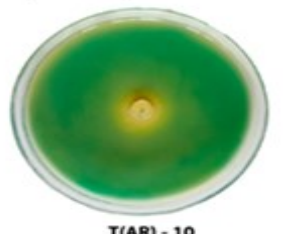

T(AR) - 10

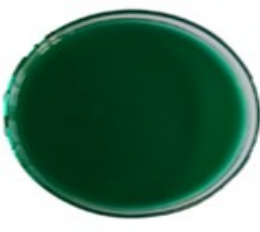

CONTROL

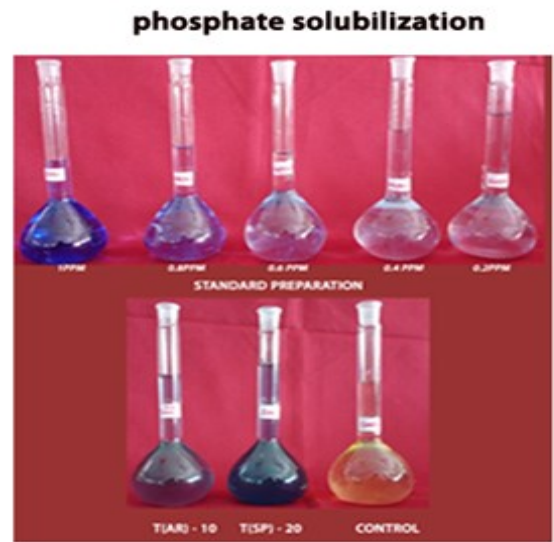

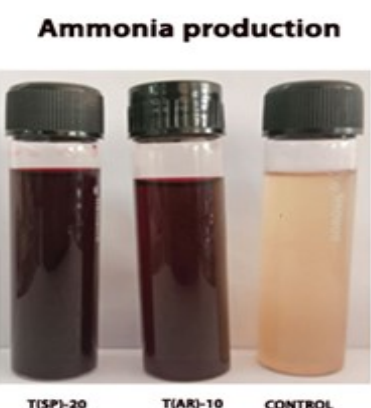

IAA production

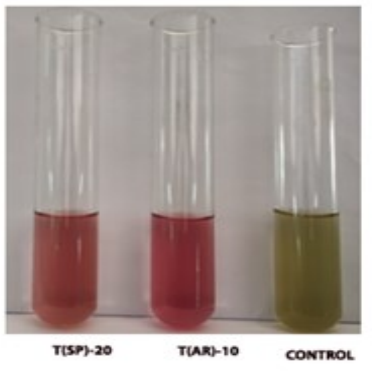

Fig. 4. Showing phytostimulation activities of Trichoderma spp.

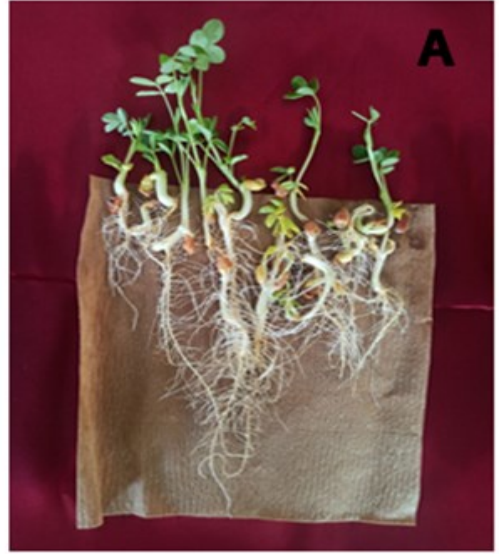

$\mathrm{T}(\mathrm{SP})-20$

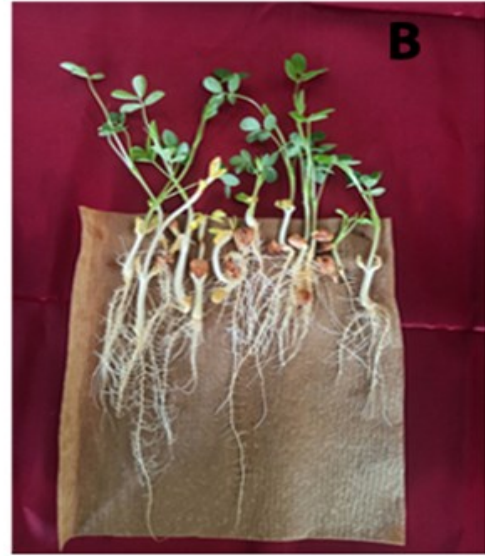

$\mathrm{T}(\mathrm{AR})-10$

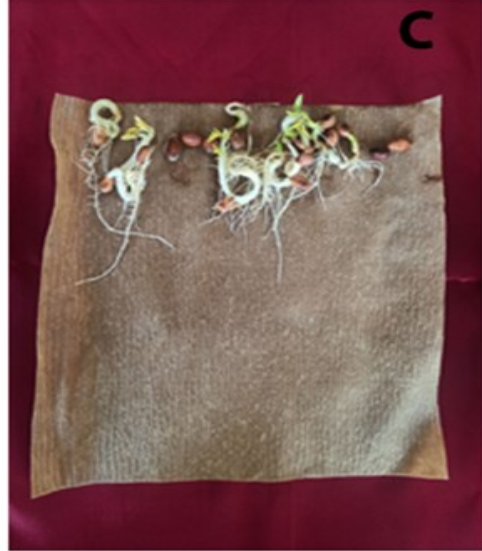

control

Fig. 5. Roll towel method:A. T(SP)-20 ( T. longibrachiatum) and B. $T(A R)-10$ (T. asperellum) treated groundnut seeds showing high shoots, root length and germination percentage, C. Control (without Trichoderma sp. treatemet) showing poor shoots, root length and germination percentage

ma spp. T(SP)-20, T(AR)-10 showed high production of siderophores than other isolates (Table 3, Fig.4). Comparable findings were reported by Zhao et al. (2014) with the siderophore-producing $T$. asperellum strain in cucumber. It boosted the available iron level in sterilized soil and increased the cucumber plants ability to absorb the nutrient elements. Our findings were in accordance with Prasad et al. (2017), who reported positive results with Trichoderma spp. isolates for ammonia production and IAA production, and siderophore production and those isolates effectively inhibited the mycelial growth of $S$. rolfsii $(95.1 \%)$.

\section{Growth promotion activities of Trichoderma spp.}

Growth promotion activities of six Trichoderma spp. were assessed by roll towel method. The resulted revealed that $\mathrm{T}(\mathrm{SP})-20$ produced a higher vigor index (2246.4) followed by T(SP)-10 (1762.2) and TNAU- TA (1341). The isolates $T(S P)-20$ and $T(A R)-10$ showed major growth-promoting activity as compared to the control. The T. longibrachiatum T(SP)-20 showed high germination percentage of $93.33 \%$, with a high shoot length of $10.6 \mathrm{~cm}$, and root length of $13.4 \mathrm{~cm}$ and this was followed by T(AR)-10(86.6) and TNAU- TA (80) as compared to the control in which germination percent- 
age was only $46 \%$ and vigor index 342 (Table 4, Fig.5). Similarly, Rajaput and Rao (2019) reported that roll towel test with $T$. harzianum treated tomato seeds revealed that seed born pathogen infection was minimized to $15.5 \%$ and produced the high seed germination percentage (92.67\%) and vigor index(2006.78) as compared to control in which the seed germination was $65 \%$ and vigor index was 1027.83. Similarly, Kumar et al. (2014) reported that $T$. harzianum treated chickpea seeds produced a high seedling length (16.50) and germination percentage $(90 \%)$, and high vigor index (1485) as compared to control (germination percentage $58 \%$ and vigor index 705.86).

\section{Conclusion}

The current investigation provided strong evidence that Trichoderma spp. isolated from groundnut ( $A$. hypogea L.) rhizosphere exhibits a great morphological and biochemical diversity. Screening of their ability to synthesize plant-growth-promoting and antifungal compounds revealed that the isolates were able to produce siderophore, synthesize IAA, and solubilize phosphate. Two Trichoderma isolates like T(SP)-20 ( $T$. longibrachiatum), $\mathrm{T}(\mathrm{AR})-10$ ( $T$. asperellum) having higher plant growth-promoting activity were considered as the elite Trichoderma spp., which may be screened for the management of groundnut stem rot in both pot and field trials.

\section{Conflict of interest}

The authors declare that they have no conflict of interest.

\section{REFERENCES}

1. Agrawal, D. P. K. \& Agrawal, S. (2013). Characterization of Bacillus sp. strains isolated from rhizosphere of tomato plants (Lycopersicon esculentum) for their use as potential plant growth promoting rhizobacteria. Int. J. Curr. Microbiol. App. Sci, 2(10), 406-417.

2. Azarmi, R., Hajieghrari, B., \& Giglou, A. (2011). Effect of Trichoderma isolates on tomato seedling growth response and nutrient uptake. African journal of Biotechnology, 10 (31), 5850-5855. https://doi.org/10.5897/AJB10.1600

3. Castle, A., Speranzini, D., Rghei, N., Alm, G., Rinker, D., \& Bissett, J. (1998). Morphological and molecular identification of Trichoderma isolates on North American mushroom farms. Applied and Environmental Microbiology, 64 (1), 133-137.

4. Carvalhais, L. C., Dennis, P. G., Badri, D. V., Kidd, B. N., Vivanco, J. M. \& Schenk, P. M. (2015). Linking jasmonic acid signaling, root exudates, and rhizosphere microbiomes. Molecular Plant-Microbe Interactions, 28(9), 10491058.

5. Contreras-Cornejo, H. A., Macías-Rodríguez, L., LópezBucio, J. S., \& López-Bucio, J. (2014). Enhanced plant immunity using Trichoderma. In Biotechnology and Biolo- gy of Trichoderma (pp. 495-504): Elsevier. https:// doi.org/10.1016/B978-0-444-59576-8.00036-9

6. Dye, D. (1962). The inadequacy of the usual determinative tests for the identification of Xanthomonas spp. New Zealand Journal of Science, 5(4).

7. Elad, Y., \& Chet, I. (1983). Improved selective media for isolation ofTrichoderma spp. orFusarium spp. Phytoparasitica, 11(1), 55.

8. Gomez, K. A., \& Gomez, A. A. (1984). Statistical procedures for agricultural research: John Wiley \& Sons.

9. Gordon, S., \& Paleg, L. (1957). Quantitative measurement of indole acetic acid. Physiol Plant, 10, 37-48.

10. Guey, N., Kumar, K., Dangue, A., \& Arama, M. (2018). Bioproduction of indol 3 acetic acid by Trichoderma strains isolated from agriculture field soils in Senegal. World J Pharmaceutical Res, 7(17), 817-825.

11. Halifu, S., Deng, X., Song, X., \& Song, R. (2019). Effects of two Trichoderma strains on plant growth, rhizosphere soil nutrients, and fungal community of Pinus sylvestris var. mongolica annual seedlings. Forests, 10(9), 758.

12. Hartmann, A., Singh, M., \& Klingmüller, W. (1983). Isolation and characterization of Azospirillum mutants excreting high amounts of indoleacetic acid. Canadian Journal of Microbiology, 29(8), 916-923. https://doi.org/10.1139/m83147

13. International Seed Testing Association (1993). Poceedings of International Seed Testing Association. International rules for seed testing. Seed Sci Technol, 21:1-152.

14. Khamna, S., Yokota, A., \& Lumyong, S. (2009). Actinomycetes isolated from medicinal plant rhizosphere soils: diversity and screening of antifungal compounds, indole-3acetic acid and siderophore production. World Journal of Microbiology and Biotechnology, 25(4), 649-655.

15. King, E. J. (1932). The colorimetric determination of phosphorus. Biochemical Journal, 26(2), 292-297. https:// doi.org/10.1042/bj0260292

16. Kumar, V., Shahid, M., Srivastava, M., Singh, A., Pandey, S., \& Sharma, A. (2014). Enhancing seed germination and vigor of chickpea by using potential and effective strains of Trichoderma species. Virology \& Mycology, 3(2), 1-3.

17. Narayanasamy, P., \& Saravana, M. (2009). RAPD analysis of Trichoderma and it's antagonistic affect with Pseudomonas fluorescens. J. Plant Pathol. Microb., 20(4), 223233.

18. Ons, L., Bylemans, D., Thevissen, K., \& Cammue, B. (2020). Combining biocontrol agents with chemical fungicides for integrated plant fungal disease control. Microorganisms, 8(12), 1930.

19. Paredes, J. A., Cazón, L. I., Osella, A., Peralta, V., Alcalde, M., Kearney, M. I., ... \& Oddino, C. (2016). Relevamiento regional del carbon del mani y estimaciones de perdidas producidas por la enfermedad. $X X X I$ Jornada Nacional de Mani, 53-54.

20. Prasad, R., Sagar, B. V., Devi, G. U., Triveni, S., Rao, S. K., \& Chari, D. (2017). Isolation and screening of bacterial and fungal isolates for plant growth promoting properties from tomato (Lycopersicon esculentum Mill.). Int. J. Curr. Microbiol. App. Sci, 6(8), 753-761.

21. Prasad, R. D., Chandrika, K. S. V. P., \& Godbole, V. (2020). A novel chitosan biopolymer based Trichoderma delivery system: Storage stability, persistence and bio 
efficacy against seed and soil borne diseases of oilseed crops. Microbiological Research, 237, 126487.

22. Rajaput, J., \& Rao, M. (2019). In vitro evaluation of antagonist's agents against seed-borne fungal diseases of tomato (Solanumly copersicum Mill.). Journal of Pharmacognosy and Phytochemistry, 8(6), 574-576.

23. Rifai, M. A. (1969). A revision of the genus Trichoderma Mycological Papers, 116, 1-56.

24. Samuels, G. J., Dodd, S. L., Gams, W., Castlebury, L. A. \& Petrini, O. (2002). Trichoderma species associated with the green mold epidemic of commercially grown Agaricus bisporus. Mycologia, 94(1), 146-170. https:// doi.org/10.1080/15572536.2003.11833257

25. Schwyn, B., \& Neilands, J. (1987). Universal chemical assay for the detection and determination of siderophores. Analytical Biochemistry, 160(1), 47-56. https://doi.org/10.1 016/0003-2697(87)90612-9

26. Shahid, D. M. (2013). Molecular characterization of Trichoderma longibrachiatum 21PP isolated from rhizo- spheric soil based on universal ITS primers. African Journal of Microbiology Research, 7, 4902-4906. https:// doi.org/10.5897/AJMR2013.5761

27. Sharma, K., \& Singh, U. (2014). Cultural and morphological characterization of rhizospheric isolates of fungal antagonist Trichoderma. Journal of Applied and Natural Science, 6(2), 451-456.

28. Siddiquee, S. (2017). Fungal volatile organic compounds: emphasis on their plant growth-promoting. In Volatiles and Food Security (pp. 313-333). Springer, Singapore.

29. White, T. J., Bruns, T., Lee, S., \& Taylor, J. (1990). Amplification and direct sequencing of fungal ribosomal RNA genes for phylogenetics. PCR protocols: A Guide to Methods and Aapplications, 18(1), 315-322.

30. Zhao, L., Wang, F., Zhang, Y., \& Zhang, J. (2014). Involvement of Trichoderma asperellum strain T6 in regulating iron acquisition in plants. Journal of Basic Microbiology, 54(S1), S115-S124. https://doi.org/10.1002/jobm.20 1400148 